\title{
Resilience of Students in Bhayangkara Jakarta Raya University whom had Character Building Program in Facing Covid-19 Pandemic
}

\author{
Rika Fitriyana ${ }^{*}$, Sarita Candra Merida ${ }^{2}$ \\ \{rika.fitriyana@dsn.ubharajaya.ac.id ${ }^{1}$ \} \\ Faculty of Psychology, University of Bhayangkara Jakarta Raya, Indonesia ${ }^{1,2}$
}

\begin{abstract}
Since March 2020, Indonesia has been fighting Covid-19 pandemic that effects people's live in almost all aspects. Difficulties are inevitable and to survive, human must have to ability to bounce back from adversity, frustration, and misfortune. In Bhayangkara Jakarta Raya University, every students learn about character building which contains several themes such as problem solving and empathy. Thus themes were aimed to help them shaping good quality within. This study aimed to find out the level of resilience of students in this pandemic situation. Method of this research was descriptive statistic to analyze information about the level of students' resilience. Online questionare were given $(\mathrm{N}=127)$ in order to collect data needed for this research. Based on data analysis, $81,1 \%$ students were able to bounce back and handle difficulties they met during this pandemic. Character Building as a subject on college helped students develop resilience within.
\end{abstract}

Keywords: Character building, pandemic, resilience

\section{Introduction}

Indonesia has been fighting Covid-19 pandemic through this 2020. Since March, the government stated an emergency status due to this situation. Indonesian Covid-19 Task Forced reported 452,291 confirmed cases until the beginning of November and the number is increasing everday [1]. In West Java, 42,572 infected and Bekasi scored 8336 total suspect. This data showed how great the increasing of reported cases happening right now.

As we know, this pandemic effects almost every aspects of human's life. Not only health, but also economic, financial, and education as well. In life, difficulties often occurred and human strive to survive. Because some individuals have the resistance to environmental risk experiences shown called resilience [2]. Youth with assets and resources will be able to develop healthy even in this kind of pandemic situation [3]. There is evidence from studies in humans and in experimental animals that resilience can result from a history of stress [4]. Stress is a reality of life and it happens as long as human exist. Stress can cause bad effect for some people, but some others don't. According to previous research, both men and women were facing several psychological problems during pandemic [5]. Including most of students whose school were closed and applied study from home at this moment.

From time to time, the definition of resilience has grown not only the ability to bounce back, but also adapting well in the face of adversity, trauma, tragedy, threats or even significant sources of stress [6]. An individual may adapt well to stress in a workplace or academic setting, but maybe not in their personal life [7]. Therefore, they should learn skill that can help them 
coping with stress and inhabit good character. Resilience relies on personal strengths as well as the resources form environment [8]. According to Dr. Rachel Yehuda, resilience can be defined as moving forward in an insightful and integrated positive manner [9].

Everyday, the number of Covid19 cases has been rising in Indonesia especially in Jakarta and West Java. University of Bhayangkara Jakarta Raya, is one of college that located in Jakarta and Bekasi, two cities that have quite high Covid19 reported case. Also effected by pandemic, this university has different ways in preparing their students in facing many difficulties in life. Through character education, students character is strengthen by special subject, called character building [10]. Every students learn about character building which contains several themes such as problem solving and empathy. Thus themes were aimed to help them shaping good quality within. Teachers are the central of natural mediator, in the level of university, lecture plays the role as teacher. Research found that teacher-delivered intervention enhancing student's resilient coping [11].

The Character Building (Table 1) is one of mandatory subjects that every students in Bhayangkara should take on their first year of college. University provide lecture with Psychological educational background that will teach this subject. Each lecture deliver the same lesson plan in all Character Building classes. Program implementation begins with lecture's meeting to ensure mutual understanding among them. On this meeting, modules are provided so each lecture can read it first before they start on assignment. Further discussion is also being maintained during session 1-16 about anything that has to do with the subject. A lecture coordinator chosen in order to monitor and evaluate this program from the beginning until the end of semester.

During session 1-16, students will learn various things about human's character, this include 2 sessions for mid and final term exam as an evaluation. The modules are designed to provide student enough information and also to reinforce life skill on shaping behavior and building positive character. This approach is based on the basic principle learning where students exercise those valuable things they learn in everday life.

Skills acquired during the program continue to be implemented and practiced throughout the years' students proceed in college. The way they behave in the class, how they interact with lecture and among friends are some of area implementation of character building. Not to mention how they deal with problems and ways to solve, also require good character. As we know, college students mostly are adolescence and early adulthood that usually have to deal with various problems (academic, interpersonal relationship, family, work, etc). Intervention to enhance resilience can be administered before, during or after stressful/traumatic situation (e.g. covid19 pandemic) [7]. 
Table 1. The Characteristic Building Program

Session 1: Human Nature
Session 2: Personality Characteristic
Session 3: Self-Acceptance
Session 4: Know Yourself
Session 5: Self-Improvement
Session 6: Social Interaction
Session 7: Social Behavior
Session 8: Human and Environment
Session 9: Moral and Virtues in Life
Session 10: Leadership
Session 11: Attitude and Respect
Session 12: Resilience
Session 13: National Security
Session 14: Self-Achievement

Though resilience may change over time as a function of development and one's interaction with the environment [7]. For example, a college student maybe resilience in facing new method on learning during pandemic, but may intervere with other problems during adolescence. Other example, student's ability in problem solving related to academic matter with personal conflict during developmental shift from adolescence to early adulthood. It is important for lecture to encourage students to implement knowledge they gain from this program into real life. Because it's really aplicable in almost every aspects of daily lives.

The purpose of this study is to find out the level of resilience of college students whom has learned character building. The method used to analyze data collected through online questionnare was descriptive statistic. Some literature review also conducted to provide theory based for the study.

\section{Method}

The method of this research used descriptive statistic to describe the level of students' resilience in University of Bhayangkara Jakarta Raya [12]. Total sample were $127(\mathrm{~N}=127)$ with online questionnare given as measurement tool. This Resilience tool was adapted from ConnorDavidson Resilience Scale (10-item CD-RISC).

\section{Results and Discussion}

Based on the calculation result data collected from 7 faculties $(\mathrm{N}=127)$; Law, Economy and Business, Computer, Communication, Education, Psychology, and Technology, level of resilience was shown in the following Table 2. 
Table 2. Level of resilience

\begin{tabular}{llcccc}
\hline & & Frequency & Percent & Valid Percent & Cumulative Percent \\
\hline Valid & Low & 11 & 8,7 & 8,7 & 8,7 \\
& Middle & 13 & 10,2 & 10,2 & 18,9 \\
& High & 103 & 81,1 & 81,1 & 100,0 \\
& Total & 127 & 100,0 & 100,0 & \\
\hline
\end{tabular}

From Table 2 the categorization showed $81,1 \%$ students have high level of resilience. While $10,2 \%$ at average level, and the rest $8,7 \%$ were low. This means that most of students are able to bounce back and handling difficulties during this pandemic. The program proved to be effective on promoting good character and behavior as well.

This finding was similar to previous study that showed students with good character bulding has good ability survive from many pressure in life [13]. Since this character building program was build through special subject that all students must take in the beginning of their study, it really helped them building resilience within.

The present study focused on delivering information about character building, this shown clearly on the theme each session. Lecture also play as role-model for student, promoting good character in everday life. Evidence indicates most of students not having trouble in handling problems, especially during this pandemic. Character building program gave positive impact. Our result suggest that this program is worth it and useful because it benefits students for the proceeding years ahead.

Table 3. Gender

\begin{tabular}{llllll}
\hline & & Frequency & Percent & Valid Percent & Cumulative Percent \\
\hline Valid & Girl & 99 & 78,0 & 78,0 & 78,0 \\
& Boy & 28 & 22,0 & 22,0 & 100,0 \\
& Total & 127 & 100,0 & 100,0 & \\
\hline
\end{tabular}

From Table 3, data showed that the respondents of this research are mostly girls (78\%), while boys are only $22 \%$. This data needed to be elaborate further for more interpretation.

\section{Conclusion}

Based on the results of this study, it can be concluded that resilience can be obtained through character education. Besides that, youth that often catalog risk and fixing problem should be provided with program that enhance support within. To enhance resilience at a specific level may involve intervention on a different level. By strengthening student's understanding through Character Building subject, University Bhayangkara Jakarta Raya has succesfully directing resilience in present and future stressful situation.

Additionally, this study suggests further elobaration on others factor such as psychological well-being, learning style, and bigger sampling among 7 faculties in University Bhayangkara Jakarta Raya. Also, it would be important to measure before-after the program was delivered to students. The number of equal gender in participants should be balanced in the next research. 


\section{Acknowledgements}

We would like to express our thanks of gratitude to our institution University of Bhayangkara Jakarta Raya, for funding our research. We also assure that there's no conflict of interest regarding the funding we accepted from institution. Our colleagues in Faculty of Psychology for their support. Our beloved student, Rospita whom had dearly helpful in collecting data. Last but not least, our beloved family for their never ending love and support.

\section{References}

[1] C. T. Force, "Covid-19," 2020.

[2] S. Cabib and P. Campus, "Learning to cope with stress: psychobiological mechanisms of stress resilience," Rev. Neurosci., vol. 23, no. November, pp. 659-672, 2012.

[3] M. A. Zimmerman, "Resiliency Theory: A Strengths-Based Approach to Research and Practice for Adolescent Health," Heal. Educ Behav., vol. 40, no. 5, pp. 381-383, 2013.

[4] M. Rutter, "Implications of resilience concepts for scientific understanding.," Ann. N. Y. Acad. Sci, no. 1094, pp. 1-12, 2006.

[5] N. Bahrul, H., Salom, G., Latifa, R., \& Indriyani, "Sikap Keberagaman, Resiliensi, dan Gangguan Psikologis di Masa Pandemi Covid-19," Cent. Appl. Psychom., p. 16, 2020.

[6] G. A. Bonanno, C. Panter-brick, and R. Yehuda, "Resilience definitions, theory, and challenges: Interdisciplinary perspectives,” Eur. J. Psychotraumatology, vol. 5, no. November, 2014.

[7] P. RH and S. Southwick, "Psychological resilience in OEF-OIF Veterans: application of a novel classification approach and examination of demographic and psychosocial correlates," J. Affect. Disord., vol. 3, no. 133, pp. 560-8, 2011.

[8] R. Lerner, "Resilience as an Attribute of the Developmental System: Comments on the Papers of Professors Masten \& Wachs," Ann. N. Y. Acad. Sci, vol. 1094, pp. 40-51, 2006.

[9] Y. R et al., "Epigenetic Biomarkers as Predictors and Correlates of Symptom Improvement Following Psychotherapy in Combat Veterans with PTSD," Front Psychiatry, vol. 4, no. Sep 27, p. $118,2013$.

[10] A. Marini and U. N. Jakarta, "Character Building Through Teaching Learning Process : Lesson In Indonesia,” Int. J. Sci. Res., vol. 73, no. May, pp. 177-182, 2017.

[11] L. Wolmer, D. Hamiel, N. Margalit, T. Versano-eisman, and Y. Findler, "Enhancing Children 's Resilience in Schools to Confront Trauma : The Impact on Teachers," no. January, 2016.

[12] S. Azwar, Penyusunan Skala Psikologi, 2nd ed. Yogyakarta: Pustaka Pelajar, 2016.

[13] A. Rachman, "A Study on Character Building Based on Habituation to Form Students ' Character," Adv. Soc. Sci. Educ. Humanit. Res., vol. 100, pp. 221-227, 2017. 